\title{
An Adaptive Re-use of Cultural Heritage Buildings in Jabodetabek (Greater Jakarta) as the National Gallery of Indonesia's Satellites
}

\author{
Yuke Ardhiati ${ }^{1}$, Ashri Prawesthi $D^{1}$, Diptya Anggita', Ramadhani Isna Putri ${ }^{1}$, L. Edhi \\ Prasetya $^{1}$, Widya Nur Intan ${ }^{1}$, Muhammad Wira Abi ${ }^{1}$, Rafli Alfiano ${ }^{1}$, Muhammad Rifqie \\ Izzulhaq $^{1}$, Raditia Raka Putra ${ }^{1}$, Chandra Arfiansyah ${ }^{1}$ \\ ${ }^{1}$ Department Architecture, Universitas Pancasila, Indonesia \\ yukeardhiati@gmail.com
}

\begin{abstract}
The Nasional Gallery of Indonesia is a reputable art gallery owned by the Indonesian State. Its roles as the venue for exhibitions and art events on an International scale. To maintain the reputation then it employed the Independent Curators to carry out exhibitions. In recent years, the phenomenon of the professional Fine Art Artists shows the hing spirits. To enrich their international publication, then they began to realize their opportunity to exhibit at this gallery. Unfortunately, the gallery building is an adaptive reuse of the Cultural Heritage Building. The National Gallery building, which has a distinctive Dutch Colonial architectural style, has not been optimally utilized. So, it has existence has broad limitations and space limitations that unable to accommodate such high interests. On the other hand, Jabodetabek stands for Jakarta-BogorDepok-Tangerang-Bekasi, the Greater City of Jakarta, with Cultural Heritage Buildings. There are many architectural styles of heritage buildings that have a chance to be the exhibition spaces. The study aims to find solutions for exhibition area availability in Jabodetabek to accommodate the Fine Art Artists' interest in exhibiting. According to the Adaptive-Reuse of the National Gallery's case, and by refers to the Grounded Theory Research method and Case Studies related to the Jabodetabek's Cultural Heritage buildings. A Working Hypothesis is Jabodetabeks's Cultural Heritage Buildings opportunities as The National Gallery's Satellites. The findings are the Satellite Galleries Rank, and the Properties Display recommendation based on the Cultural Heritage's rules that can be offered to make them the "Satellite" and the ICOM as to the National Gallery Indonesia's standard.
\end{abstract}

(C) 2020 IJBESR. All rights reserved.

Keywords: Adaptive Reuse, Jabodetabek’s Heritage Buildings, National Gallery, "Satellite"

\section{Introduction}

The Nasional Gallery of Indonesia is a reputable art gallery owned by the Indonesian State. It is usually called Galnas, is located as a Cultural Heritage of the Dutch Colonial era. Refers to Soekarno policy in the Pembangunan Nasional Pola Semesta Berentjana 8 Tahun Pertama 1961-1969 [1], the Nasional Gallery within origin entitled Gallery Kesenian
Nasional. The national policy included the 335 projects named A, and Project B is how to fund Project A. [2]. Because of the political situation, then the formal institution of Nasional Gallery of Indonesia as the Soekarno's origin idea is unbuilt.

In other words, The Nasional Gallery of Indonesia just the idea of President's Soekarno. 
International Journal of Built Environment and Scientific Research p-issn: 2581-1347 | e-issn: 2580-2607 | Pg. 115 - 126

Moreover, 30 years after His great idea, the Art Venue is not yet built. Finally, The Nasional Gallery of Indonesia was created. One of the heritage building was located in surround the District of Power during the Soeharto's Era by occupancy. By named The Nasional Gallery of Indonesia [3]. Historically, the Galnas were done among the efforts carried out to establish the National Cultural Development Center Program (Wisma Seni Nasionall Pusat Pengembangan Kebudayaan Nasional) in the Soekarno era in the 1960s.

To the realization of the National program, then Prof. Dr. Fuad Hasan, on behalf of the Minister of Education and Culture, organized the renovation of the Heritage Building to be the Culture Art Exhibition, as role as a center for art appreciation art venue by renovated the old building in 1987. After the process to be The Nasional Gallery of Indonesia, the Galnas started to operate on May 8, 1999. As the Art Gallery venue, Galnas roles as a museum of art and the center of fine arts to enhance the public appreciation of the artworks through the agenda of protection, development, and utilization of the artworks in Indonesia. [4]

As well as the gallery, Galnas roles as the venue for exhibitions and art events on International scale. To maintain the reputation then it employed the Independent Curators to carry out exhibitions. By invited the Independent Curators from various Fine Art background studies, the gallery can facilitate the Indonesian Fine Artist and abroad to show their work for the purpose of their exhibition's theme. In recent years, the phenomenon of the professional Fine Art Artists shows the hing spirits. To enrich their international publication, then they began to realize their opportunity to exhibit at this gallery.

Finally, the Galnas also role a tourist destination and the graphic based on the registration book. Annually, visitors increase
Volume 04 Number 02 | December 2020

[5]. Refers to him, in $2013 \quad(65.804$ visitors/year), 2014 (77.842 visitors/year), 2015 (139.470 visitors/year), and 2016 (257.309 visitors/year). The Galnas peak visitors on the three events of August in 2017, 2018, and 2019. Is the serial event are part of Indonesia's Independence Anniversaries during 2016-2018.

The Presidential Palaces' Office had created three times of Temporary Art Exhibition. It's held to give chance opportunities to the public to enjoy, appreciate, and to the marvel of the Presidential Palace's art collection entitled "1771: Goresan Juang Kemerdekaan" or "The Brush Strokes of the Struggle for Independence." It shows 28 artworks from Soekarno's art collections. It was curated by Mikke Susanto and Rizki A. Zaelani [6].

The second was held in August 2017, namely "Senandung Ibu Pertiwi" or "Our Motherland's Melody." Four curators curated it; Asikin Hasan, Amir Sidharta, Mikke Susanto, and Selly Texania [7]. And the third in 2018 entitled "Indonesia Semangat Dunia" or" Indonesia as Spirit of the World." Two curators curated it; Amir Sidharta and Watie Moerany [8]. The exhibition's theme was inspired by Asian Games XVIII, an international event held in August. The third of Presidential Palaces exhibitions during 2016 - 2018 had a role as the Presidential artworks showcases.

Unfortunately, the gallery building is an adaptive reuse of the Cultural Heritage Building. The National Gallery building, which has a distinctive Dutch Colonial architectural style, has not been optimally utilized. Because of created by occupant the Old Building in a limited site, then the Galnas started had many problems, especially in a storage room, space of exhibition and others.

Related to the Galnas building condition, Mahendra had identified the Galnas problems, among others; (a) the storage collection that is 
not representative area, and the collections vulnerable to damage, (b) the building $\mathrm{C}$ condition, as the storage room, conservation laboratory and showroom is cracked on the wall. (c) The complicated arrangement of the Permanent Exhibition Room (2nd floor) without the emergency exit access, (d) the public complaints from the fine arts community that exhibits and organizers, due to the limited in duration of the exhibition.

After two decades operated, Galnas had contributed to develop the Indonesian Artist to show their best fine artworks. But, it has no facilitated room to support to be an international of Nasional Gallery, among others; (a) the VVIP Room Facilities, (b) the Gallery dimension and height, (c) the temporary exhibition, etc.

Based on the National Gallery's idealistic, The Galnas plan to extend the building by creating Gallery Nasional Competition twice [9]. Because of the political situation, then the plans are canceled. Meanwhile, great enthusiasm for Indonesian Artists needs to show their exhibition in Galnas. On the other hand, Galnas has a limitation to facilitate.

\section{Material and Methods}

The study aims to suggest the Galnas's problem related to the exhibition space by purposes the Galnas's extended spaces in other locations in Jabodetabek. The Jabodetabek stands for Jakarta-Bogor-Depok-Tangerang-Bekasi are the Greater City of Jakarta, has Cultural Heritage Buildings. There are many architectural styles of heritage buildings that have a chance to be the exhibition spaces.

Related to the study aim, then the study refers to accommodate the Grounded Theory. By purpose, a Working Hypothesis is the several Jabodetabeks's Cultural Heritage Buildings had opportunities to be The National Gallery's Satellites.

\subsection{The Jabodetabek's Role as Jakarta Hinterland}

Refers to Peraturan Presiden Republik Indonesia No. 54 Tahun 2008 [10] related to the Capital City of Jakarta Hinterland, there are Jakarta, Depok, Tangerang, Bogor dan Bekasi which is a megapolitan area of Jakarta and its surroundings. In surround of Jabodetabek have more than buildings roles as Cultural Heritage Buildings. The study has preferred one building as the representation of the Jabodetabek's hinterland, among others:

\section{(a) Jakarta City}

The contents of SK Gubernur of Jakarta No. 475 Tahun 1994 related to Building Cultural Heritage include the number of heritage buildings around 132 buildings. After its revision in 2018, the heritage building in Jakarta around 600 units [11]. The buildings are located into two categories, (a) located at Old City of Jakarta (Kota Tua) and (b) Located in the Central of Jakarta City of the Colonial buildings and the Building in Early Independent in Soekarno's era.

One of Jakarta's heritage buildings is the use of the Terminal Building of Kemajoran Airport of Jakarta. Based on Ardhiati's book [12], it has $166.875 \mathrm{~m} 2$ is a potential role to be an Art Venue.

\section{(b) Bogor City}

Bogor City has 24 of Cultural Buildings

[13] among others:

(1) Balaikota Bogor

(2) Gedung Keresidenan Bogor

(3) Markas Kodim 0606 Bogor

(4) Markas Korem 061/Suryakencana

(5) Gedung Blenong/ BPN

(6) Gedung RRI Regional II Bogor

(7) Museum Tanah

(8) Balai Penelitian Perkebunan

(9) Kantor Pos Bogor

(10) Lembaga Pemasyarakatan Bogor

(11) Museum Zoologi Bogor 
(12) Monumen dan Museum PETA

(13) Makam Raden Saleh

(14) Gereja Katedral

(15) Zebaot

(16) Gedung SMA YZA 2

(17) Gedung SMP N 2 Bogor

(18) Gedung SMP 1

(19) Stasiun Kereta Api

(20) Rumah Sakit Salak

(21) Rumah Panti Asuhan Bina Harapan

(22) Hotel Salak

(23) Mesjid Empan

(24) Klenteng Dhanagun

(25) Prasasti Batutulis

Based on her research before in Bogor, the Museum Tanah Building in Bogor is also has chance to be an Art Venue.

\section{(c) Depok City}

Refers to Tri Wahyuning Irsyam (2020) as the Leader of Tim Ahli Cagar Budaya Kota Depok - TACBK Depok, [14] the Cultural Heritage Buildings in Depok are:

(1) Rumah Cimanggis [15]

(2) Kantor YLCC

(3) GIPIB Immanuel

(4) Pemakaman Kamboja

(5) Rumah Edward Soedira

(6) Rumah Sakit Harapan

(7) SDN 2 Pancoran Mas

(8) SMA Kasih

(9) Rumah Tinggal Pendeta GPIB

(10) Jembatan Panus

One of them that has chance to be an Art Venue is "Rumah Cimanggis". It has the an artistically of building house than can to be an nice art space.

\section{(d) Tangerang City}

Refers to Tim Ahli Cagar Budaya (TACB) of The Provinsi Banten [16] among others:
(1) Ex. Karaton Banten
(2) Museum Pemasyarakatan di LP Anak Wanita,

(2) Rumah Asli Kolonial at Kelurahan Sukajadi,

(3) Makam Yudhanegara di Sangiang,

(4) Makam TB. Mas Zakaria at Batuceper,

(5) TMP Taruna Cemetery,

(6) Rumah Gede Asrama Polisi at Ciledug and

(7) Rumah Lim Tian Tiang at Karawaci.

One of them that has chance to be an Art Venue is the sorrounding of Ex. Karaton Banten. It potentially to be an Out Door Art Venue that suitable with the New Normal of the Pandemic Covid-19.

(e) Bekasi City [17]

(1) Rumah adat Bekasi at Kranggan, Jatisampurna,

(2) Sumur Kembar Kranggan 1, Bantar Gebang,

(3) Sumur Kembar Kranggan 2, Bantar Gebang,

(4) Tugu Perjuangan Kali Bekasi,

(5) Tugu Perjuangan Rakyat Bekasi, Alun-alun Kota Bekasi,

(6) Tugu Bambu Runcing, Hutan Kota Bekasi,

(7) Tugu Perjuangan Jalan H Agus Salim,

(8) Gedong Papak and

(9) Sumur Kembar.

One of Tangerang City's Building Heritage, the Sumur Kembar, has a chance to be an Art Venue. It is located in the surrounding of the sacred space, but it could potentially be an Out Door Art Venue that is suitable for the Art Sacred Space purpose.

\subsection{Research Method and Theory}

Related to the Cultural Heritage Buildings in Jabodetabek, more than 1.492 intangible and tangibles of Indonesia's historical buildings were registered and identified. For many cases, they were revitalized based on the Republic of 
Indonesia's cultural preservation law number 11 in 2010 (The Republic of Indonesian Law. No. 11, 2010). Both have enriched civilization. One point in this Law is An Adaptive Reuse, like the revitalized methods to revitalize them. The essential method of Adaptive Reuse is described as a process by which structurally old buildings/old artifacts are developed to generate an economic value [18].

By refers to an Adaptive Reuse method of "De Tjolomadoe"- the sugar factory was held by retrofitting old buildings for a new use. It allows the existing structures to retain their historical integrity to the modern functions/ occupants. Meanwhile, an Adaptive Reuse must pay attention to climate and International Heritage Instruments [19]. Adaptive Reuse is different from restoration or preservation. At the same time, restoration or preservation of a heritage building involves restoring a building to its original state. Adaptive Reuse changes the intent of a structure to meet the modern user's needs. In this case, the old building was damaged, and the architectural style was unrecognized. Because of it, then during an Adaptive Reuse process is need to reveal the original architecture style.

To find the building façade, an architectural image archive is needed. This was done to ensure that the similarities between the original design drawings and heritage buildings were tracked. Unfortunately, the archives of the old building did not provide beforehand, so it is necessary to explore many resources to redraw the heritage buildings to purpose to be a similar role and the center of an exhibition to support the Gallery Nasional of Indonesia.

The gallery itself has a role as a space to show the Art of Exhibition. In that term, an art gallery is also a role in the museum's gallery, so they have the same approach on how to show the artifact to public appreciation.

\subsection{The Art Gallery's Role of The New Normal}

During the New Normal in 2020, Architect may create the imaginary art space digitally. The term is related to a new digital phenomenon. The virtual museum may create based on an imaginary art gallery/ art museum building virtually. An imaginary art gallery/museum building means created a building in imagination. It is not real to build but shows all collections need to compose an architecture building event. It is just imaginary.

According to the virtual museum, the Architect may create his/her imaginary art gallery/museum building to show the artifacts collection digitally. By creating an imaginary building, as his/ her considered to the millennial taste. To convey the culture to future generations, it needs an attractiveness to invite them into cyberspace. To fit with the New Normal, then the study need to contribute to the New Normal by purpose the Jabodetabek's hinterland to be the art gallery spaces as well as their heritage characteristic.

\subsection{The Contemporary Theory of Art Gallery}

To enrich the Jabodetabek's cultural heritage to be the Satellite Galleries, the study refers to the recent museum's/ art gallery theories. One of them is "The 10 Trends of Museum" [20], a museum design have changed among others; (a) Hybrid. The museum must create a 'Hybrid Spaces' to collaborate with other parties as an example is the "Te Papa" Museum's Learning Lab in New Zealand, (b) Instagram Ready. The museum must arrange with attractive settings to be ready to air on instagram's screen, an example, "The Ice Cream Museum" in Los Angeles (April 2017) than in New York (June 2017), (c) Well-Being.

The Museum of Art Galleries must hold for the sake of the feeling of prosperity together. "Well-Being" concept was created with other 
International Journal of Built Environment and Scientific Research p-issn: 2581-1347 | e-issn: 2580-2607 | Pg. 115 - 126

art performances, for example, dances, songs, music, films, (d) Touchpoint. A museum section is permitted to be touch (can be by a replica) or something like a 'pop up' artifact as a supporter, as an example: The Jewish Museum Frankfurt's Pop-Up Monument on the WillyBrandt-Platz, Then, (e) Chatting. The conventional museum needs to be changed to have an area to keep in touch between visitors, (f) Social Justice. The museum needs to incorporate media social elements in order friendly to the millennial generation, (g) New Realities from Information to Experience. The museum must 'dare' a novelty element, (h) New Normal. The museum must be designed in new unique things related to hot issues that were originally taboo, (i) Remapped.

The museum/ art gallery must be reviewing the procedures for collections display related to hot issues/trends, (j) Agility Is the New Stability. The museum must be designing a 'novelty' by reflects the agility. By consideration with "The 10 Trends of Museum" above, a museum storyline museum still the important part. It has the role to guide visitors by plotting artifacts to show the museum collections.

A naive and unique idea maybe became a trending topic on social media to be the museum's positioning. Related to an imaginary museum building, "the Social Justice" accommodated by incorporated the mp4 video with the press social elements in order friendly to the millennial generation.

Related to conveying culture to future generations, it needs an attractiveness to invite them in cyberspace. They need the beauty of the imaginary building. On of the Architecture theory related to creating a dramatic architecture design is the "Trans-Architecture" or "An Architecture-Event" theory refers to Derrida, [21].
Volume 04 Number 02 | December 2020

\subsection{Redrawing the Old Building by BIM}

To accommodate the new role of Jabodetabek's cultural heritage to be the Satellite Galleries, it needs to redraw all of the potential buildings as the basic design information. By refers to Building Infomation Modelling (BIM), several old buildings can show reconstructed imagery and show their new role as the art gallery space.

BIM itself means a process of architectural work starts with creating a digital 3D model as a virtual/imaginary building and contains all the information of the building design, which serves as a means to make planning, design, implementation of construction, and maintenance of the building, also the infrastructure for all parties of the project such as consultant, owner, and contractor [22].

One of the BIM's goals is to create the 3D Animation of Building Reconstruction. The digital software in architecture is a tool for Architects to visualize his/her new or old projects, start from the preliminary schematics to construction documentation. The 2D architectural drawing then continues into the 3D of architectural 'form'/shape.

In virtually, then Architect Architects help to reconstruction the ruined or the damaged of a heritage building by redraw and rebuilt as well as the real building. By used the digital software addresses to help the audience understand the Architect's plan.

To improve the Architect presentation, the Lumion 3D's prominent software was published, like the one of architecture software to present the 3D architectural video. Related to the heritage building reconstruction project, the Architect may use the documentary film to understand the original building 'form' and façade to show that the heritage building's extended role refers to Ardhiati [23]. Several architectural drawings are still likely to be reconstructed through a computer program called "digital application of 3D modeling to 
cultural heritage". The 3D animation of architecture simulation was made through the 3D modeling software to show the actual reconstruction done to reduce the building failures.

To prepare the Jabodetabek cultural building's role as the new function as the Satellite of the Galnas, then it started to prepare into the 3D architecture animation refers to Lumion 3D that created based on The Sketchup software.

Lumion software is the prominent fastest 3D rendering for Architectural work. In minutes you can visualize the CAD's model in a video that shows a real-life image (Lumion, 2109) [24].

The architecture model animation created the Mp4 Video itself within the Lumion 3D program. Then, combine the Mp4 Video of an old building with the imaginer of the 3D building to show the New of The Old building performing refers to Ardhiati[25].

The Lumion software has simple tools, is relatively easy, and has a plug-in to easily and quickly process. The old archives of "Rumah Cimanggis" and "used Terminal of Kemayoran Airport" were modified into CAD-software. The Cad Software for professional projects may have not suitable for the 3D of Lumion software. Then all archives are needed to convert into the SketchUp program. SketchUp is an appropriate $3 \mathrm{D}$ design software to make the 3D modeling whatever you can imagine, especially the Sketchup version 2015 had compatible export to the Lumion 6.0 program. The Lumion 3D software is software has a level of images/ material resolution that is quite realistic. It has tools and menus that are relatively easy and simple to use.

In comparison with similar software, the 3DS Max software is an excellent output because it is almost as realistic as rendering, but 3DS Max has more tools and menus that tend to be more challenging to use and not practical. The process design there is the description phase of
3D of the video animation process, among others: (1) The Schematic design, among others; (a) determine the type and function of design/ building, (b) determine the basic ideas/ concepts of the building' form.'

Referring to the "Rumah Cimanggis" construction, (c) make a design of transformation sketch to visualize the architectural forms, (d) would be better to create the illustration in several alternative designs, (e) create/ copy the selected design sketches to the computer and keep as the basic idea to create a 3D model by using the SketchUp application, (e) after the 3D model and the architecture detailing are complete, then enter the 3D. The coloring stage is needed to clear the material specifications. For example, glasses are given a transparent color. The floor is colored with marble material, etc. (f). After the Schematic Design of the 3D model is completed, enter the animation output stage with the final output as mp4 makes the 2D images as the pdf's final output.

The second step is the 2D Images Phase, among others:

Determine the location of the building section with the tool section in the Sketchup 3D model. Determine several horizontal building pieces (plan) to vertical pieces (building section). Export the view section to the Autocad (DWG) format by Autocad 2015 version. Edit the 2D images that have been exported using Autocad software and plotting images to pdf format.

The AutoCAD software is used because it is more commonly used for 2D image output work. Compare to other similar software such as ArchiCad or Revit of Architecture software.

Finally, the mp4 was created from the old architectural drawing archives of "Rumah Cimanggis" and "The Used Building of Kemayoran Airport". Modified into SketchUp and exported the view section drawing of the Autocad 2015 version. Then, it was created to be an animation output by plotting the 2D 
images. After all of the video scenes are rendered in mp4 format, they continued into Camtasia Studio 8 serial version.

\section{Results and Discussion}

The results findings are, among others:

1. The Satellite Galleries Rank.

2. The Properties Display recommendation based on Cultural Heritage's rules.

3. Visual Display exhibition ide for the Cultural Heritage Building.

(1) The study result of the Satellite Galleries Rank is the five Cultural Heritage buildings rank that has a chance to be the "Satellite" of the National Gallery of Indonesia's standard among others:

1. Jakarta, the users of the building terminal of the Kemajoran Airport of Jakarta

2. Bogor, The Museum Tanah

3. Depok, the old building of "Rumah Cimanggis."

4. Tangerang, ex. Karaton Banten

5. Bekasi, Sumur Kembar

The study also results in the idea "Satellite" of the National Gallery of Indonesia virtually.

(2) Based on the limitation to display inside he heritage buildings, so they study will purpose the properties show recommendation based on the cultural heritage's rules among others; (a) the two dimensional (2D) works by mobile display characteristic, (b) the three dimensional (3D) works by mobile display characteristic, and (c) the mixed medias display, (3) Finally, we will propose the all visual display of The Satellite Galleries.

There are the following result study, (A) the 3D ideas of the Satellitte Galleries:

1. The Art Venue of. Ex Kemajoran Airport of Jakarta

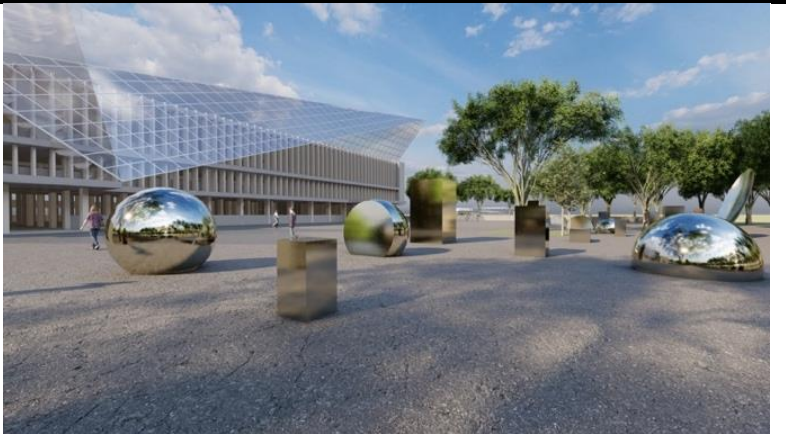

Source: Diptya Anggita, Ashri Prawesthi D \& Rafli Alfiano, 2020

Fig. 1. An Out Door Art Space's idea in Ex. Kemayoran Jakarta

2. Art Venue Idea of The Museum Tanah Bogor

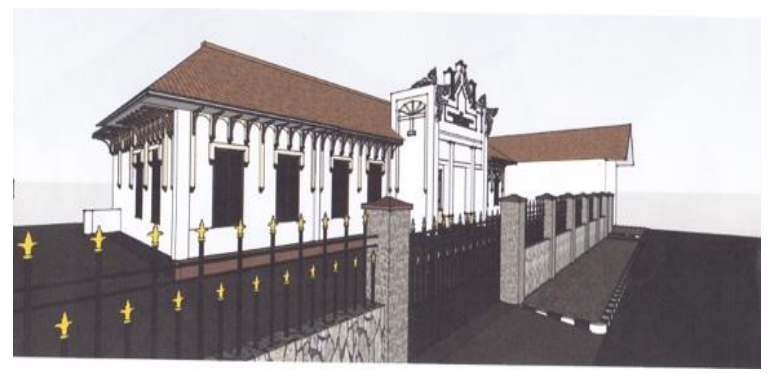

Source: Yuke Ardhiati \& Muhamad Wira Abi, 2020

Fig. 2. The Redrawing of Museum Tanah of Bogor

\section{3. "Rumah Cimanggis" Art Space in Depok}

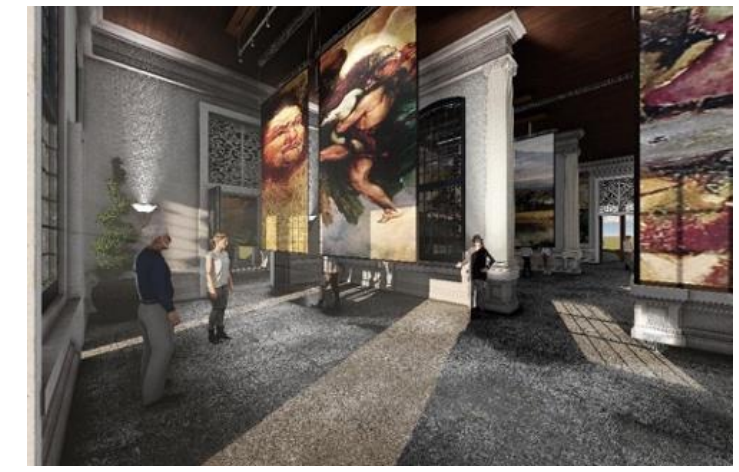

Source: Yuke Ardhiati \& Febri W Kurniawan, 2020

Fig. 3. The imaginary exhibition of "Rumah Cimanggis" 
4. The Outdoor Art Space of ex. Karaton Banten, Tangerang

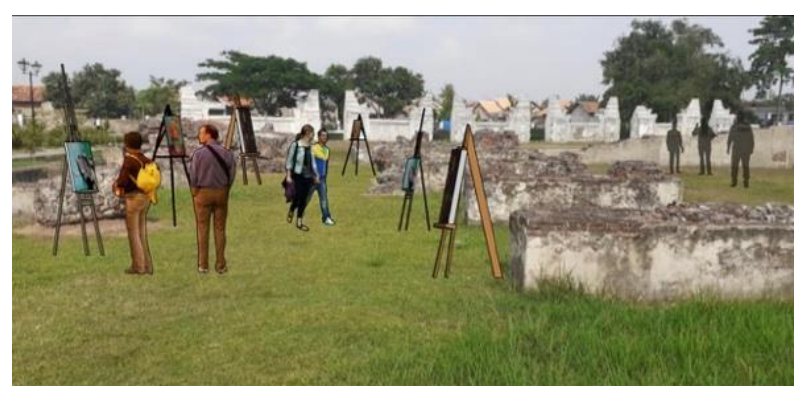

Source: Ramadhani Isna Putri \& Widya Nur Intan, 2020

Fig. 4.Free Standing art displays at Banten

5. The Sacred Space of Sumur Batu of Bekasi

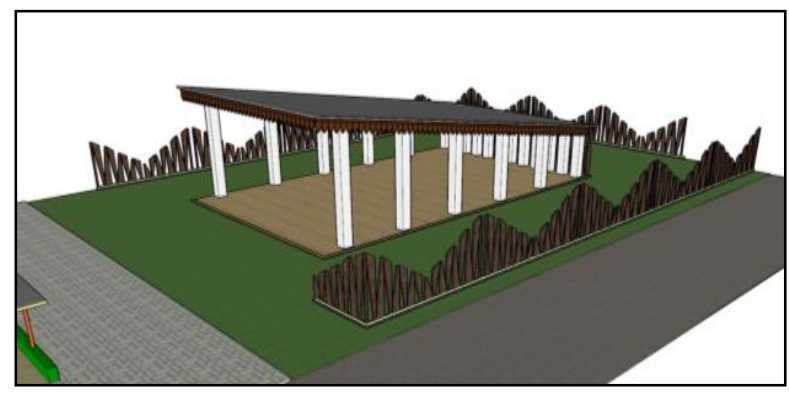

Source: L. Edhi Prasetya \& Muhammad Wira Abi, 2020

Fig. 5. 3D of Art Sacred Space at Sumur Batu

(B) The Ideas Of Standing Of Art Display:
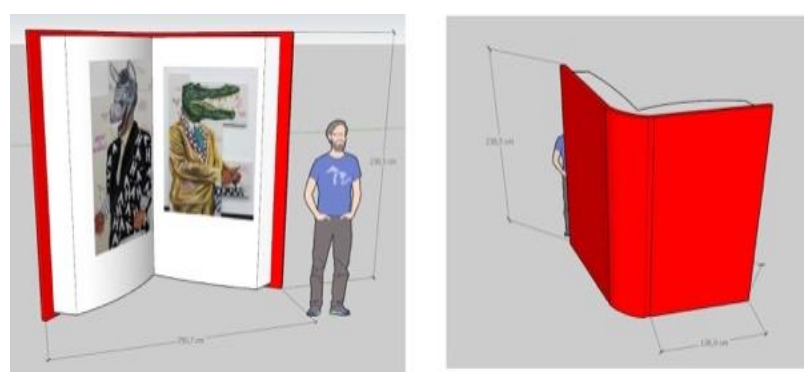

Source: Chandra Arfiansyah, 2020

Fig. 6. A Free Standing Art Display Unit of Outdor Ar Space

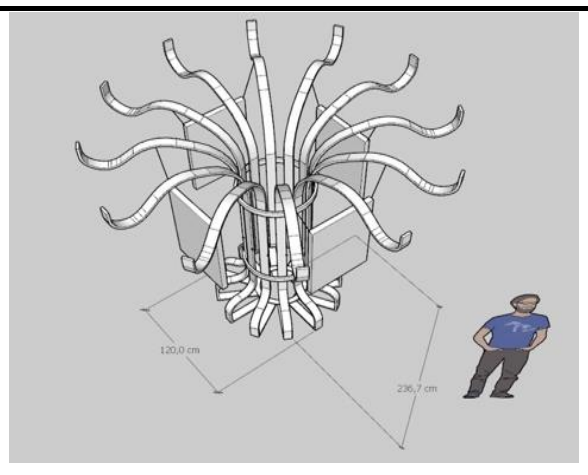

Source:Chandra Arfiansyah, 2020

Fig. 7. An Free Standing Art Display Unit

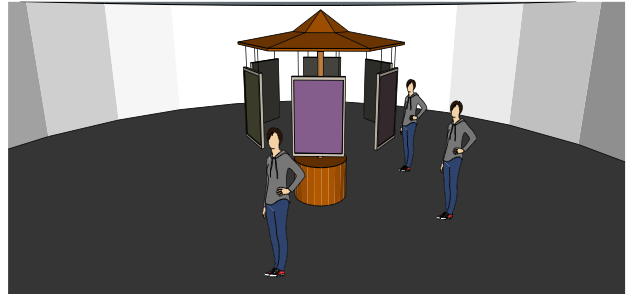

Source: Raditya Raka Putra, 2020

Fig. 8. A Free Standing Display Ideas

(C) The Imaginary Art Space in video's link Rumah Cimanggis Art Space in youtube channel

https://www.youtube.com/watch?v=cRppNAn $4 \mathrm{Hqs}$

\section{Discussion}

Refers to Grounded Theory Research, we categorized the huge data. At this phase, the study will show the mp4 Video of all of the-"Satellite" of the National Gallery of Indonesia by show the mp4 Video of "Rumah Cimanggis." The 3D Model Animation of "Rumah Cimanggis" itself results from Building Information Models (BIM). Meanwhile, the mp4 Video of others is in progress.

By referring to an architectural re-drawing, the study can contribute to the Galnas officer to consider the opportunities of Jabodetabek's cultural heritage to be the Satellite Galleries. By showing the mp4 Video of them, then hopefully 
International Journal of Built Environment and Scientific Research p-issn: 2581-1347 | e-issn: 2580-2607 | Pg. 115 - 126

Volume 04 Number 02 | December 2020

the owner/ authorities of Jabodetabek's cultural heritage buildings among others;

1. Jakarta, the users of the building terminal of the Kemajoran Airport of Jakarta to be a Contemporary Art Space

2. Bogor, The Museum Tanah to be an excellent art space

3. Depok, the old building of "Rumah Cimanggis" to be a colonial's art space

4. Tangerang, ex. Karaton Banten tobe an outdoor art space

5. Bekasi, Sumur Kembar to be a sacred art space

\section{Conclusion}

The Satellite of Gallery Nasional is a series of Heritage Buildings located in Jabodetabek that can be the extension of the Gallery Nasional of Indonesia. They would be role as the art space of exhibition by referring to the Gallery Nasional of Indonesia's requirement. By creating The Satellite of Gallery Nasional, the Galnas can facilitate the Indonesian artist and aboard to show their work. It will collect a huge work of art and President Soekarno's idea related to Gallery Nasional in the 1960s [26].

During its process to be, the study will be contributed by presenting the mp4 Video of the $3 \mathrm{D}$ architecture model. One of them is the imaginary Gallery of "Rumah Cimanggis" and "The Used Building of Kemayoran Airport" in order then stakeholder of art can watching on cyberspace.

By creating the mp4 Video of the 3D architecture model, it is the potential to cut off the significant budget of construction. The Satellite of Gallerie National will show without to build physically. The virtual gallery's digital application based has cut off the extraordinary effort included; (a) limitation of space, (b) limitation of budget, (c) limitation of real collections, (d) limitation of times.
By uploading the mp4 Video into YouTube Channel, then the Satelite of Gallery Nasional of Indonesia has a chance to public easily to access. By refers the method then was accommodated with Industry 4.0 as well public and the millennial generation can learn among others; (a) imaginary of an architectural design before revitalization, (b) the ideas of art displays in Cultural Heritage Building, (c) how to purpose an art space by cut off time and budget. Finally, the idea of the Satellite of Galery Nasional cans shows through the mp4 Video of "Rumah Cimanggis" and "The Used Building of Kemayoran Airport" in cyberspace to reach everyone everywhere and every time.

\section{Acknowlegement}

We would like to appreciate the Gallery Nasional of Indonesia officers to collaborate with research within this theme.

\section{References}

[1] Ardhiati, Yuke. (2005). Bung Karno Sang Arsitek. Kajian Artistik Karya Arsitektur, Tata Ruang Kota, Interior, Kria, Simbol, Mode Busana dan Teks Pidato 1926-1965. Komunitas Bambu: Depok.

[2] Said, M (ed.)(1961). Pedoman Untuk Melaksanakan Ampera Jilid I \& II. Pedarmilda, Surabaya.

[3] Galeri Nasional Indonesia: The National Art Gallery. http://galeri-nasional.or.id/1999.

[4] Jakartabytrain.com, 2013.

[5] Mahendra, Jarot. (2017). Sudut Pandang Baru Terhadap Revitalisasi dan Adaptasi Kompleks Gedung Galeri Nasional Indonesia. Seminar Ikatan Peneliti Lingkungan Binaan Indonesia (IPLBI) 1, B 247-254. Retrieve from https://seminar.iplbi.or.id/wpcontent/uploads/2017/06/HERITAGE2017-B247-254-Sudut-Pandang-Baru-TerhadapRevitalisasi-dan-Adaptasi-Kompleks-GedungGaleri-Nasional-Indonesia.pdf

[6] Susanto, M. and Zaelani, R.A. (2016). 1771: Goresan Juang Kemerdekaan (1771: The Brush Strokes of the Struggle for Independence). Jakarta: The Ministry of Presidential Secretary.

[7] Hasan, A., Sidharta, A., Susanto, M., and Texania, S. (2017). Senandung Ibu Pertiwi (Our 
Motherland's Melody). Jakarta: The Ministry of Presidential Secretary.

[8] Sidharta, A. and Moerany, W. (2018). Indonesia Semangat Dunia. (Indonesia, Spirit of the World.) Jakarta: The Ministry of Presidential Secretary.

[9] IAI website.

[10] Peraturan Presiden Republik Indonesia Nomor 54 Tahun 2008 tentang Penataan Kawasan Jakarta, Bogor, Depok, Tangerang, Bekasi, Puncak Cianjur.

[11] Megapolitan.kompas.com (2018). Bangunan Cagar Budaya di Jakarta Sebanyak 600 Unit . retrieved in 19/02/2018, 21:01 WIB https://megapolitan.kompas.com/read/2018/02/ 19/21013061/bangunan-cagar-budaya-dijakarta-sebanyak-600-unit.

[12] Ardhiati, Yuke and Hasan, Asikin (2019). Tiga Relief Tiga Perupa. Narasi Keindonesiaan di Ruang VIP Eks. Bandaa Kemayoran Jakarta. Direktorat Kesenian, Direktorat Kebudayaan. Kementrian Pendidikan dan Kebudayaan RI.

[13] Radar Bogor.com.(2020). Ada 24 Bangunan Bersejarah di Kota Bogor, Tim Cagar Budaya Dibentuk. 24 Februari 2020 10:15 WIB https://www.radarbogor.id/2020/02/24/ada-24bangunan-bersejarah-di-kota-bogor-tim-cagarbudaya-dibentuk/

[14] Metro.tempo.com.(2010). Cagar Budaya Depok, 9 Bangunan Kuno Masuk Nominasi. https://metro.tempo.co/read/1215361/cagarbudaya-depok-9-bangunan-kuno-masuknominasi

[15] Kompas.com (2019).Selain Rumah Cimanggis, 9 Bangunan Bersejarah di Depok Diusulkan Jadi Cagar Budaya https://megapolitan.kompas.com/read/2019/06/ 18/05150041/selain-rumah-cimanggis-9bangunan-bersejarah-di-depok-diusulkan-jadi.

[16] Kabar Banten. (2018). Kota Tangerang Akan Punya 7 Cagar Budaya Baru. https://www.kabar-banten.com/kota-tangerangakan-punya-7-cagar-budaya-

baru/\#: :text=Sebanyak\%20tujuh\%20cagar\%2 Obudaya\%20baru,akan\%20ditetapkan\%20pada $\% 20$ tahun\%20ini.\&text=Adapun\%20kesembil annya\%20adalah\%20Masjid\%20Kalipasir,dan \%20Vihara\%20Boen\%20Tek\%20Bio.

[17] Bisnis.com (2017). 8 Situs di Kota Bekasi Jadi Cagar Budaya. Bisnis.com. 23 Oktober 2017.

https://jakarta.bisnis.com/read/20171023/383/7 02167/8-situs-di-kota-bekasi-jadi-cagar-budaya

[18] Bedate, A., Herrero, L. C., and Sanz, J. Á. (2004). Economic Valuation of The Cultural Heritage: Application To Four Case Studies in Spain.
Journal of Cultural Heritage, 5(1), 101-111. Retrieved April 7, 2019. Doi: http://dx.doi.org/10.1016/j.culher.2003.04.002

[19] Sheridan, R. And Sheridan, J. (2013). International Heritage Instruments and Climate Change. Illinoir, Common Ground The Inclusive Museum.

[20] NEMO - Network of European Museum Organizations. (2017, September 17). Museum Trends and Prospects for 2018. Retrieved August 17, 2018 from https://www.pinterest.co.uk/pin/112519690677 062427/

[21] Derrida, J. (1986). Point De Folie Maintenant L'Architecture. Bernard Tschumi: La Case Vide - La Villette, 1985. Architectural Association School of Architecture, 12, pp. 65-75. Retrieved January $18, \quad 2017 \quad$ from https://www.jstor.org/stable/29543519?seq=1

[22] Ardhiati, Y. (2020)." The Extended Role Of Building Information Models (BIM): Mp4 Video Of The Monument Of Gelora Bung Karno of Jakarta". A|Z ITU Journal of Faculty Architecture. Online First Article. http://www.azitujournal.com/jvi.aspx?pdir=ituj fa\&plng=eng\&list=inpress

[23] Cantor, Jeremy. \& Valencia, Pepe. (2004). Inspired 3D Short Film Production. USA: Thomson Course Technology PTR.

[24] Lumion 9 (2019). Get the latest version of your favorite $3 D$ rendering software. Retrieved from https://lumion.com/upgrade.html.

[25] Ardhiati, Y, Prawesthi, D.A, Prasetya, L.E \& Kurniawan, F. (2019). "Imaginary Vs. Traditional Museum: The Historical HeritageBased Design". Seminar International HUNIAN of Universitas Brawijaya of Malang. https://download.atlantispress.com/proceedings/hunian-19/125942536

[26] National Archive. (1960). Pembangunan Semesta Berentjana Tahap I 1961 - 1968 
International Journal of Built Environment and Scientific Research p-issn: 2581-1347 | e-issn: 2580-2607 | Pg. 115 - 126

(This page is intentionally left blank) 